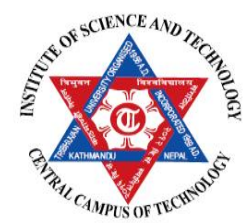

\title{
Moisture Sorption Characteristics of Weaning Food
}

\author{
${ }^{a, b}$ Kabindra Bhattarai $*,{ }^{a, b}$ Babita Adhikari, ${ }^{a}$ Prabina Ghimire \\ aDepartment of Food Technology, Central Campus of Technology, Tribhuvan University, Dharan, Nepal \\ ${ }^{\mathrm{b} C e n t r a l}$ Department of Food Technology, Institute of Science and Technology, Tribhuvan University, Dharan, Nepal \\ *Corresponding email: kabindra.bhattarai@cct.tu.edu.np
}

\begin{abstract}
Stickiness and caking are the significant problems for food powders due to moisture migration from the storage environment. This study was conducted to determine the moisture sorption isotherm of weaning food (Nutrilac and Superceral) and to fit the sorption data in different sorption isotherm models. Static gravimetric method was used to determine the equilibrium moisture content (EMC) at $22-89 \% \mathrm{RH}$ at $30^{\circ} \mathrm{C}$. The EMC data obtained were plotted to the models Brunauer Emmet Teller (BET), Guggenheim Anderson and De Boer (GAB). Results indicated that sorption isotherms were of type II isotherm according to Brunauer et al., (1940) classification. BET model was fitted to the sorption data with coefficient of regression 0.985 and 0.986 for Nutrilac and Supercereal respectively. The GAB model was fitted with coefficient of regression 0.983 and 0.979 for Nutrilac and Supercereal respectively. Monolayer moisture content determined from the BET and GAB model at $30^{\circ} \mathrm{C}$ were 1.63 and $2.24 \mathrm{~g} / 100 \mathrm{~g}$ dry matter for Nutrilac and 1.51 and $2.26 \mathrm{~g} / 100 \mathrm{~g}$ dry matter for Supercereal respectively.
\end{abstract}

\author{
Article Info \\ Article history: \\ Received date: 02 June 2020 \\ Accepted date: 15 September 2020
}

\section{Introduction}

Weaning foods are the foods specially prepared so that they are easy for the growing age children to eat and digest. They are complementary foods an infant and child given in addition to breast-milk and are prepared from various blends of cereals, pulses, and oilseed flour and milk solids (Atal, 2003). The quality of these dried powder products is largely dependent on its moisture content, moisture migration and/or moisture uptake of the food during storage. Therefore, the water activity level, which corresponds to a range of equilibrium moisture contents, must be determined, for example, the use of moisture isotherms (Atal, 2003; Mageea et al., 2010).

Caking is a serious problem for dried powder products because it cause decrease in solubility, increase in lipid oxidation and enzymatic activity, loss of flavor and crispness and also decrease the shelf life (Chen, 1998). The shelf life and storage stability of foods are influenced by their moisture sorption characteristics that are often represented by moisture sorption isotherms, which are plots of moisture content versus water activity at certain temperatures (Atal, 2003; Baskaran et al., 2000). Sorption data are always useful in the formulation of shelf stable foods. It often signifies the capacity of a particular product to retain the moisture at a particular humidity, also called hygroscopicity of a substance. Highly hygroscopic substance exhibits a steep isotherm while the sparingly hygroscopic has flat sorption isotherm. The knowledge and understanding of the sorption isotherm of food is important for solving problems in thermodynamics, structure investigations and in unit operations such as drying, mixing, packaging, for estimating the microbiological, chemical and physical stability of food, etc. (Gal, 1983).

There are different isotherm equations developed to describe the sorption behavior and thermodynamic property of foods. Usually the equation that best fits the particular food material is used to describe the sorption behavior of particular food material. The equations developed are empirical, semi-empirical or theoretical type (Khanal, 2004). 
Brunauer Emmet Teller (BET) equation is one of the most popular sorption isotherm equations. This equation can be derived based on the kinetic statistical mechanics or thermodynamic consideration (Timmermann et al., 2001). From this model, two constants namely the monolayer moisture content and the energy constant $C_{B}$ can be obtained. Despite the theoretical limitations of BET adsorption analysis, the BET monolayer concept was found to be a reasonable guide for preservation and packaging of dried foods (Iglesias \& Chirife, 1982). According to Labuza \& Rahman (2007) this equation can be used upto water activity 0.55 and according to Timmermann et al. (2001) it can be used upto 0.4. The BET equation can be considered to be the most useful for determining the optimum moisture conditions for good storage stability, especially for dehydrated food products (Arslan \& Togrul, 2006). The BET equation in a linear form is as follows (Timmermann et al., 2001).

$$
\frac{a_{w}}{M_{e}\left(1-a_{w}\right)}=\left(\frac{C_{B}-1}{X_{m B} C_{B}}\right) a_{w}+\frac{1}{X_{m B} C_{B}}
$$

Where, $a_{w}=$ Water activity

$\mathrm{M}_{\mathrm{e}}=$ Equilibrium moisture content

$\mathrm{X}_{\mathrm{mB}}=$ Monolayer moisture content (BET monolayer)

\section{$\mathrm{C}_{\mathrm{B}}=$ Energy constants of BET equation}

Guggenheim Anderson and De Boer (GAB) equation is one of the most widely used isotherm equation to describe sorption behavior of foods. This equation is best fit in the water activity range of 0.10 0.90 (Timmermann et al., 1989). It has been found to best fit the starchy food products (Leindo-Cardenas et al., 2000). According to (Bizot, 1983) the GAB equation is as follows;

$$
\frac{M_{e}}{X_{m G}}=\frac{C_{G} K a_{w}}{\left(1-K a_{w}\right)\left(1-K a_{w}+C_{G} a_{w}\right)}
$$

Where, $\mathrm{M}_{\mathrm{e}}=$ Equilibrium moisture content in dry basis

$$
\begin{aligned}
& \mathrm{X}_{\mathrm{mG}}=\text { Monolayer moisture } \\
& \mathrm{K}=\text { Energy constant of GAB equation } \\
& \mathrm{C}_{\mathrm{G}}=\text { Guggenheim constant }
\end{aligned}
$$

Monolayer moisture content is the amount of moisture content in the material when the water molecule is just sufficient to cover the surface molecule by a single layer of molecule. At this moisture content the product is most stable to chemical, physical and microbiological deterioration. The monolayer moisture content of the product determined by BET and GAB equations is not equal and experimentally, it has been found that GAB monolayer moisture content is always greater than BET monolayer value. The GAB monolayer moisture content is $10-40 \%$ higher than the BET monolayer moisture content. It has been concluded that the GAB monolayer moisture content represents the better physical reality of starchy product (Timmermann et al., 2001).

The BET monolayer moisture content $\left(\mathrm{X}_{\mathrm{mB}}\right)$ of taro flour was found to be $3.57 \mathrm{~g} / 100 \mathrm{~g}$ at $25^{\circ} \mathrm{C}$ (Owuamanam et al., 2010), infant milk $3.46 \mathrm{~g} / 100 \mathrm{~g}$ (Prasad \& Agrawal, 2012), tea $4.6 \mathrm{~g} / 100 \mathrm{~g}$ (Khanal, 2004), puffed rice $5.73 \mathrm{~g} / 100 \mathrm{~g}$ at $30^{\circ} \mathrm{C}$ (Rijal, 2007) and that of beaten rice was found to be $5.03 \mathrm{~g} / 100 \mathrm{~g}$ (Bhattarai., 2012). The difference in data may be due to variation in sample. The energy constant $\left(C_{B}\right)$ within (2-50) indicate type II isotherm (Labuza, 2002). The prediction of $\mathrm{X}_{\mathrm{mB}}$ values is important since deterioration of foods is very small below $X_{\mathrm{mB}}$, since water is strongly bound to the food below $\mathrm{X}_{\mathrm{mB}}$ and is not involved in any deteriorative reaction either as solvent or as one of the substrates (Kaymak-Ertekin \& Gedik, 2004).

The GAB monolayer moisture for infant milk was $3.58 \mathrm{~g} / 100 \mathrm{~g}$ (Prasad \& Agrawal, 2012), and taro flour $4.23 \mathrm{~g} / 100 \mathrm{~g}$ (Owuamanam et al., 2010), beaten rice $7.53 \mathrm{~g} / 100 \mathrm{~g}$ (Bhattarai., 2012), puffed rice $6.69 \mathrm{~g} / 100$ $\mathrm{g}$ (Rijal, 2007) and that of tea was found to be $4.4 \mathrm{~g} / 100$ g (Khanal, 2004). Since the GAB model covers the entire water activity range, its monolayer value has been suggested to give a better representation of the safe moisture content of agricultural product.

\section{Materials and Methods}

\subsection{Material collection}

The samples of weaning food (Nutrilac and Supercereal) were collected directly from Nutri foods Pvt. Ltd., Biratnagar, Nepal.

\subsection{Methods}

\subsubsection{Preparation of different $R H$ environment}

Eight different saturated salt solutions were made from potassium hydroxide, magnesium chloride, potassium thiocynate, sodium bromide, sodium nitrite, sodium chloride, potassium dichromate, and barium 
chloride to give the relative humidity values (22-89)\% at $30^{\circ} \mathrm{C}$ as given by (Greenspan, 1977). Uniform sized glass desiccators of internal diameter $180 \mathrm{~mm}$ and height $200 \mathrm{~mm}$ were used. Around $25 \mathrm{~mm}$ of the bottom was filled with saturated solutions.

\subsubsection{Determination of sorption isotherm}

A static gravimetric technique was used to get the equilibrium moisture content data of the weaning food. 10 gram powder samples were put in the tared Petridish and two such dishes were placed in each desiccators having $22,31,45,58,67,79,86$, and $89 \%$ relative humidity. These 8 desiccators were in turn placed inside temperature-controlled cabinet at $30^{\circ} \mathrm{C}$. The mass transfer between the sample and the environment in the desiccators is by natural diffusion process. The loss or gain in weight of the sample was observed in the interval of $1 \mathrm{~h}$ up to $6 \mathrm{~h}$ and thereafter, in the interval of $24 \mathrm{~h}$ until constant weight was obtained. Then, the equilibrium moisture content was determined by Wink's weight method.

\subsubsection{Determination of proximate components}

The proximate components moisture, protein, fat, crude fiber and ash content of weaning food was determined as described in (Rangana, 2010).

\subsection{Data analysis}

The experimental data of equilibrium moisture content was used to obtain the linear and polynomial regression lines by using the Microsoft Excel 2007 software.

\section{Results and Discussion}

The sample of weaning food (Nutrilac and Supercereal) was brought from the industry and the proximate analysis was done. The equilibrium moisture content at different relative humidity (22.0$89.0 \%$ ) was determined using static gravimetric method at temperature $30^{\circ} \mathrm{C}$. The data obtained were fitted to different models (BET equation, GAB equation) and the model parameters were determined.

\subsection{Proximate composition}

The proximate composition of weaning food is presented in Table 1. The values lie within the specification given by World Food Programme for Supercereal Corn Soya Blend (WFP, 2013).
Table 1: Proximate composition of weaning food

\begin{tabular}{lll}
\hline Components & Nutrilac $(\mathbf{d b \%})$ & Supercereal $(\mathbf{d b \% )}$ \\
\hline Moisture & $4.60(0.38)$ & $4.30(0.35)$ \\
Crude protein & $18.76(0.25)$ & $20.48(0.41)$ \\
Crude fat & $6.15(0.23)$ & $6.38(0.15)$ \\
Crude fiber & $1.99(0.45)$ & $2.30(0.10)$ \\
Total ash & $2.09(0.31)$ & $2.72(0.17)$ \\
Carbohydrate $^{*}$ & $71.01(0.45)$ & $68.12(0.74)$ \\
\hline
\end{tabular}

*The data obtained are the mean of triplicate and the valued in the parenthesis are the standard deviations.

\subsection{Sorption isotherm}

The obtained equilibrium moisture content (EMC) of weaning food at different storage conditions is presented in Table 2. The sorption isotherm has a characteristic sigmoid shape type II isotherm for nutrilac (Fig. 1) and for supercereal (Fig. 2). The curve shows a linear increment in the moisture content to water activity range of $0.45-0.79$ after which there is a steep rise in the moisture uptake.

Table 2: Equilibrium moisture content of weaning food at different relative humidity

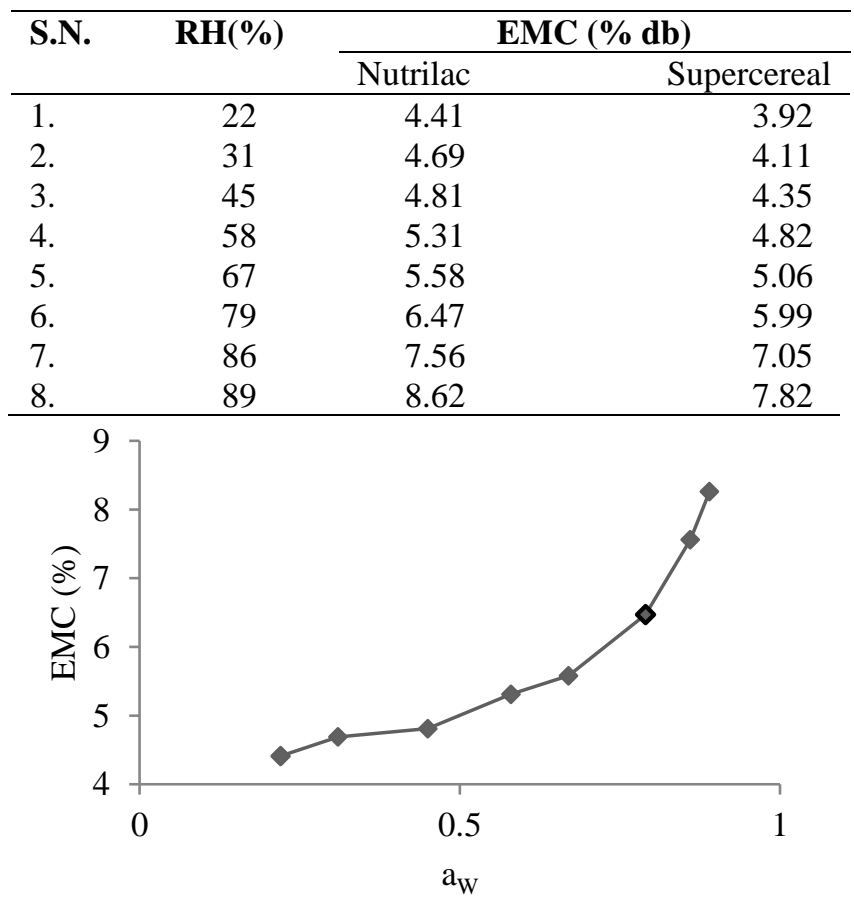

Fig. 1: Moisture sorption isotherm of Nutrilac at $30^{\circ} \mathrm{C}$

These are typical type II isotherms (Fig. 1 and Fig. 2) and have been reported for starchy products such as potato and wheat starch (Igbeka et al., 1975). The regression coefficient between water activity and moisture content for Nutrilac and Supercereal at $30^{\circ} \mathrm{C}$ was found to be 0.821 and 0.848 respectively.

The moisture uptake trend was similar to the work reported by various researcher for supplementary foods 
(Baskaran et al., 2000), rice flour (Sandoval et al., 2011), skimmed milk powder (Stencl, 1999), puffed rice (Rijal, 2007), and beaten rice (Bhattarai, 2012).

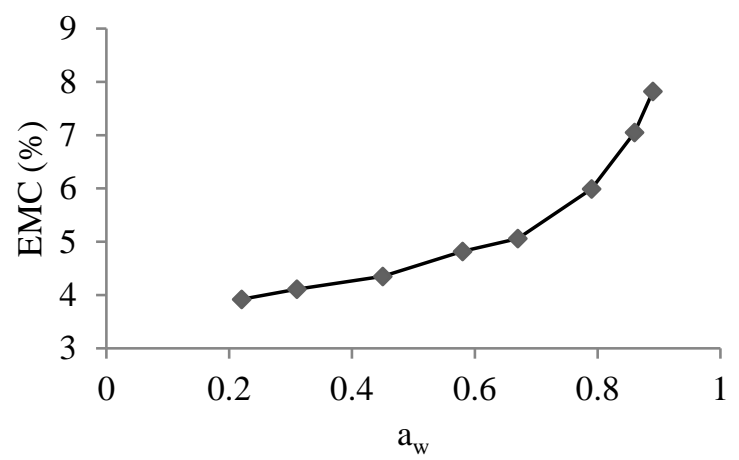

Fig. 2: Moisture sorption isotherm of Supercereal at $30^{\circ} \mathrm{C}$

\subsection{Fitting the experimental data in sorption models}

The experimental data were fitted in the BET and GAB sorption isotherm models to obtain the equation parameters.

\subsubsection{Brunauer Emmet Teller (BET model)}

The equation was obtained by plotting the aw/Me $\left(1-a_{w}\right)$ vs $a_{w}$, and the plot yield was linear in nature which is shown in Fig. 3 for Nutrilac and Fig. 4 for Supercereal.

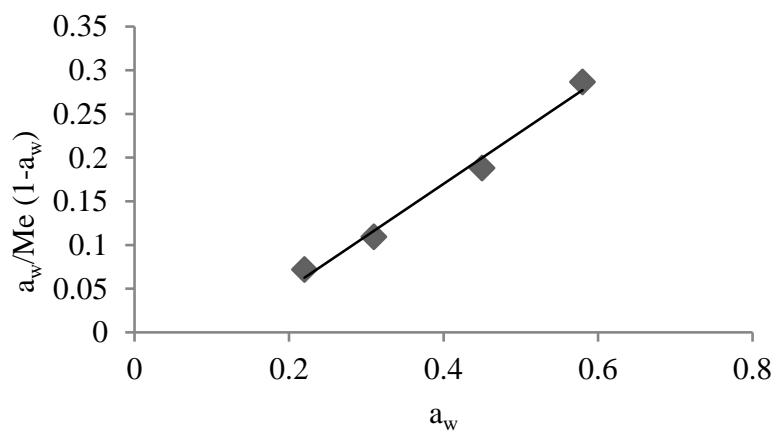

Fig. 3: BET model of experimental data of Nutrilac at $30^{\circ} \mathrm{C}$.

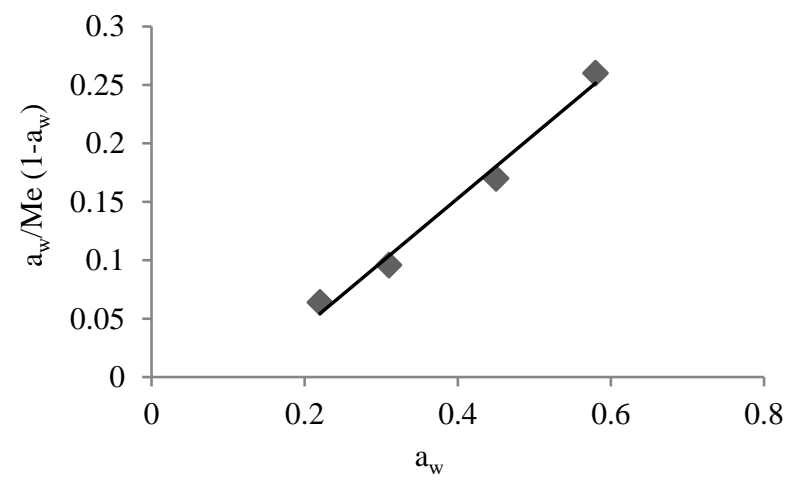

Fig. 4: BET model of experimental data of Supercereal at $30^{\circ} \mathrm{C}$

Iglesias and Chirife (1976) stated that the BET model is known to hold good for the water activity up to 0.5 . The data used for plotting were of water activity range $0.22-0.58$. The fit of the data is good as seen from the $\mathrm{R}^{2}$-value which is found to be 0.985 and 0.986 for Nutrilac and Supercereal respectively.

The monolayer moisture, energy constant, was found to be $1.63(\mathrm{~g} / 100 \mathrm{~g}$ dry matter) and 9.288, respectively for Nutrilac and 1.51 and 9.765 for Supercereal respectively. The monolayer moisture value was found to be lower than puffed rice (Rijal, 2007) and of beaten rice (Bhattarai., 2012). The energy constant $\left(\mathrm{C}_{\mathrm{B}}\right)$ has value within 2-50 which indicates that the curve is type II isotherm (Labuza, 1980). The prediction of $\mathrm{x}_{\mathrm{mB}}$ values is important since deterioration of foods is very small below $\mathrm{x}_{\mathrm{mB}}$, since water is strongly bound to the food below $\mathrm{x}_{\mathrm{mB}}$ and is not involved in any deteriorative reaction either as solvent or as one of the substrates (Kaymak-Ertekin \& Gedik, 2004).

\subsubsection{Guggenheim Anderson and De Boer (GAB model)}

The GAB working equation obtained from the experiments was plotted (Fig. 5 for Nutrilac and Fig. 6 for Supercereal). The value of $C_{\mathrm{G}}, k$ and $\mathrm{x}_{\mathrm{mG}}$ were determined by the polynomial fitting (Table 3 ). The fit of the data is good as seen from the $\mathrm{R}^{2}$ value which is found to be 0.983 and 0.979 for Nutrilac and Supercereal respectively.

Table 3: Values of constants and coefficient of regression for GAB model

\begin{tabular}{|c|c|c|}
\hline Parameter & Nutrilac & Supercereal \\
\hline $\begin{array}{l}\mathrm{X}_{\mathrm{mG}}(\mathrm{g} / 100 \mathrm{~g} \\
\text { dry matter })\end{array}$ & 2.34 & 2.26 \\
\hline $\mathrm{C}_{\mathrm{G}}$ & 23.21 & 22.12 \\
\hline $\mathrm{K}$ & 0.79 & 0.689 \\
\hline $\mathrm{R}^{2}$ & 0.983 & 0.979 \\
\hline
\end{tabular}

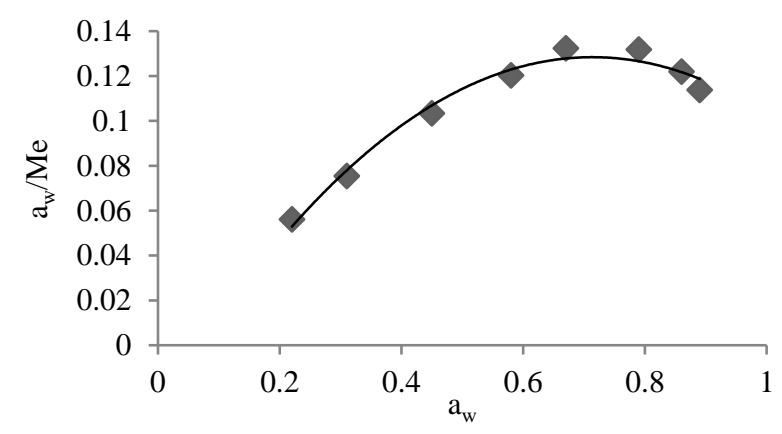

Fig. 5: GAB plot of the experimental data of Nutrilac at $30^{\circ} \mathrm{C}$ 


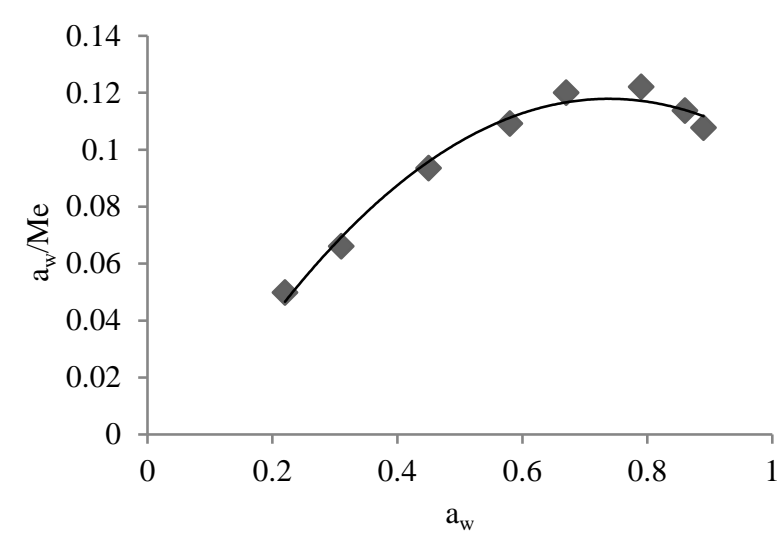

Fig. 6: GAB plot of the experimental data of Supercereal at $30^{\circ} \mathrm{C}$

The monolayer moisture of weaning foods were found to be lower than of infant milk (Prasad \& Agrawal, 2012), taro flour (Owuamanam et al., 2010), beaten rice (Bhattarai, 2012), puffed rice (Rijal, 2007) and tea (Khanal, 2004). Since the GAB model covers the entire water activity range, its monolayer value has been suggested to give a better representation of the safe moisture content of agricultural product. The sorption isotherms data obtained from the predicted $\mathrm{GAB}$ equation for nutrilac (Fig. 7) and for supercereal (Fig. $8)$.

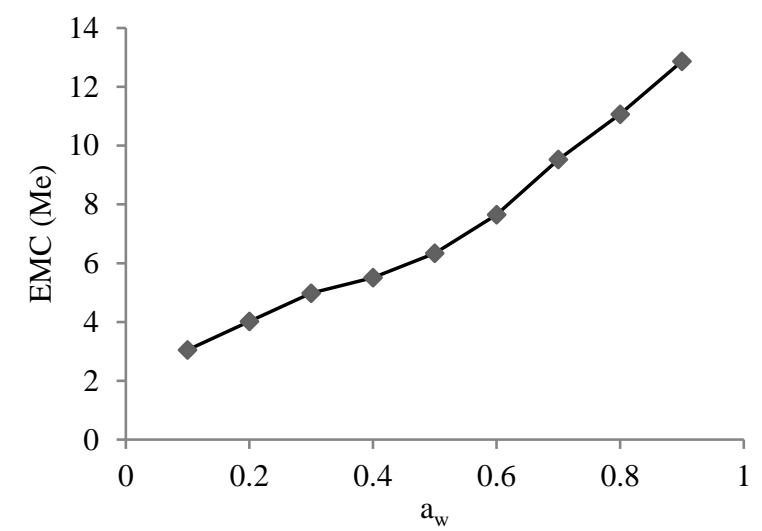

Fig. 7: Sorption isotherm of Nutrilac predicted from the $\mathrm{GAB}$ equation at $30^{\circ} \mathrm{C}$

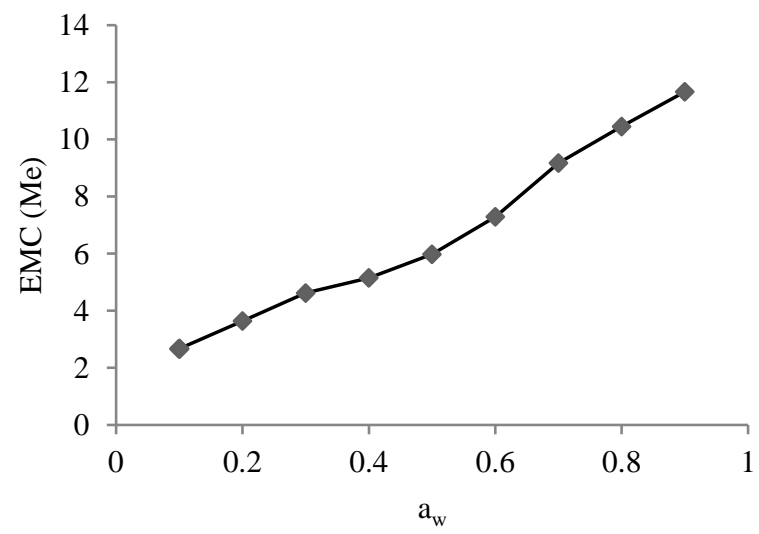

Fig. 8: Sorption isotherm of Supercereal predicted from the $\mathrm{GAB}$ equation at $30^{\circ} \mathrm{C}$

\section{Conclusions}

The conclusion drawn from the study is that the moisture sorption isotherm of the weaning food according to Brunauer et al, (1940) classification was type II (sigmoid shape). The experimental values could be modeled using BET and GAB Polynomial models using the nonlinear regression. The monolayer moisture content for weaning food obtained from BET model was lower than that obtained from GAB model at $30^{\circ} \mathrm{C}$.

\section{Acknowledgments}

The authors would like to acknowledge the Central Campus of Technology, Dharan, for providing necessary facilities.

\section{Conflicts of Interest}

The author states no conflicts of interest.

\section{Funding}

This research received no external funding.

\section{References}

Arslan, N., \& Togrul, H. (2006). The fitting of various models to water sorption isotherms of tea stored in a chamber under controlled temperature and humidity. Journal of Stored Products Research, 42(2), 112-135.

Atal, p. (2003). Formulation and Quality Evaluation of Low Cost Weaning Food Enriched with Iron. B.Tech thesis, Tribhuvan University, Nepal,

Baskaran, V., Balasubramanyam, N., Malleshi, N. G., \& Lokesh, B. R. (2000). Moisture sorption isotherms of nutritious supplementary foods prepared from cereals and legumes for feeding rural mothers and children. European Food Research and Technology, 211(1), 27-31.

Bhattarai, K. (2012). Study on the moisture sorption characteristics of beaten rice (chiura). M.Tech. thesis, Tribhuvan University, Nepal,

Bizot, H. (1983). Using the 'GAB' model to construct sorption isotherms. Physical properties of foods, 43-54.

Brunauer, S., Deming, L. S., Deming, W. E., \& Teller, E. (1940). On a theory of the van der Waals adsorption of gases. Journal of the American Chemical society, 62(7), 1723-1732. 
Chen, P. L. (1998). Study of caking using NMR. Retrieved on 24 july 2016 from website: www.tc.umn.edu/ chenx088/research.php?topic=caking

Gal, S. (1983). Necessary of sorption isotherm evaluation. In R. Jowitt, F. Escher, F. Hallstrom, H. F. T. Meffert, W. F. L. Spices, and G. Vos (Eds.), Physical properties of food. London: Applied Science Publishers.

Greenspan, L. (1977). Humidity fixed points of binary saturated aqueous solutions. Journal of research of the national bureau of standards, 81(1), 89-96.

Igbeka, J. C., Blaisdell, J. L., Herum, F. L., \& Hamdy, M. Y. (1975). Equilibrium moisture content of cassava and potato. American Society of Agricultural Engineers, Paper, (75-6527).

Kaymak-Ertekin, F., \& Gedik, A. (2004). Sorption isotherms and isosteric heat of sorption for grapes, apricots, apples and potatoes. LWT-Food Science and Technology, 37(4), 429-438.

Khanal, D. (2004). Study on moisture sorption behaviour of CTC black tea. (M. Tech. Thesis), Tribhuvan University, Nepal.

Labuza, T. P. (1980). The effect of water activity on reaction kinetics of food deterioration. Food Technology, 34(4), 36-41.

Labuza, T., \& Rahman, M. S. (2007). Water activity and food preservation. Handbook of food preservation, New York: Taylor and Francis Group, 447-476.

Liendo-Cardenas, M., Zapata-Norena, C. P., \& Brandelli, A. (2000). Sorption isotherm equations of potato flakes and sweet potato flakes. Brazilian Journal of food technology, 3, 53-57.
Mageea, T. R. A., Neilla, G., and Al-Muhtasebb, A. H. (2010). Moisture sorption characteristics of heat treated flour, culinary flour and high ratio cake. Q18.

Owuamanam, C. I., Ihediohanma, N. C., \& Nwanekezi, E. C. (2010). Sorption isotherm, particle size, chemical and physical properties of cocoyam corm flours. Researcher, 2(8), 11-19.

Prasad, D., and Agrawal, A. K. (2012). Sorption isotherms of infant milk food - Effect of variation of temperature and comparison of various constants in BET and GAB models. Indian Journal of Dairy Science, 65(6), 499-455.

Rangana, S. (2010). Handbook of Analysis of Fruit and Vegetable Products. (2nd ed.). New Delhi: Tata McGraw-Hill Publishing Company Limited.

Rijal, P. (2007). Study on moisture sorption characteristics. (B.Tech Thesis), Tribhuvan University, Nepal.

Sandoval, A. J., Barreiro, J. A., \& Müller, A. J. (2011). Determination of moisture adsorption isotherms of rice flour using a dynamic vapor sorption technique. Interciencia, 36(11), 848-852.

Stencl, J. (1999). Water activity of skimmed milk powder in the temperature range of 20-45 C. Acta Veterinaria Brno, 68(3), 209-215.

Timmermann, E. O., Chirife, J., \& Iglesias, H. A. (2001). Water sorption isotherms of foods and foodstuffs: BET or GAB parameters?. Journal of food engineering, 48(1), 19-31.

WFP. (2013). Super cereal -Corn soya blend for Cuba. Retrieved from 29 July 2016 from the website www.wfp.org.

How to cite: Bhattarai, K., Adhikari, B., \& Ghimire, P. (2020). Moisture Sorption Characteristics of Weaning Food. Himalayan Journal of Science and Technology, 3-4, 45-50. 